\title{
Fecal Microbiota Transplantation in the Treatment of Chronic Pouchitis: A Systematic Review
}

\author{
Frederik Cold ${ }^{1,2,+}$, Sabrina Just Kousgaard ${ }^{3,4,+} \oplus$, Sofie Ingdam Halkjaer ${ }^{2}$, \\ Andreas Munk Petersen 2,5, Hans Linde Nielsen ${ }^{4,6} \mathbb{D}$, Ole Thorlacius-Ussing ${ }^{3,4}$ \\ and Lars Hestbjerg Hansen ${ }^{1, *}$ \\ 1 Department of Plant and Environmental Sciences, Section for Microbial Ecology and Biotechnology, \\ Copenhagen University, Thorvaldsensvej 40, 1871 Frederiksberg C, Denmark; frederik.cold@regionh.dk \\ 2 Gastrounit, Medical Division, Copenhagen University Hospital Hvidovre, 2650 Hvidovre, Denmark; \\ sofie.ingdam.halkjaer@regionh.dk (S.I.H.); andreas.munk.petersen@regionh.dk (A.M.P.) \\ 3 Department of Gastrointestinal Surgery, Aalborg University Hospital, 9100 Aalborg, Denmark; \\ s.kousgaard@rn.dk (S.J.K.); otu@rn.dk (O.T.-U.) \\ 4 Department of Clinical Medicine, Aalborg University, 9100 Aalborg, Denmark; halin@rn.dk \\ 5 Department of Clinical Microbiology, Copenhagen University Hospital Hvidovre, 2650 Hvidovre, Denmark \\ 6 Department of Clinical Microbiology, Aalborg University Hospital, 9100 Aalborg, Denmark \\ * Correspondence: lhha@plen.ku.dk \\ $\dagger$ These authors contributed equally to this work.
}

Received: 25 August 2020; Accepted: 16 September 2020; Published: 18 September 2020

check for

\begin{abstract}
The objective was to evaluate available literature on treatment of chronic pouchitis with fecal microbiota transplantation (FMT) focusing on clinical outcomes, safety, and different approaches to FMT preparation and delivery. A systematic review of electronic databases was conducted using Medline, EMBASE, and the Cochrane Central Register of Controlled Trials Library from inception through April 2020. Human studies of all study types reporting results of FMT to treat chronic pouchitis were included. Nine studies, reporting FMT treatment of 69 patients with chronic pouchitis were found eligible for the review. Most studies were case series and cohort studies rated as having fair to poor quality due to high risk of bias and small sample size. Only one randomized controlled trial was included, finding no beneficial effect of FMT. In total clinical response after FMT was reported in $14(31.8 \%)$ out of 44 evaluated patients at various timepoints after FMT, and clinical remission in ten $(22.7 \%)$ patients. Only minor self-limiting adverse events were reported. FMT varied greatly regarding preparation, length of treatment, and route of delivery. The effects of FMT on symptoms of chronic pouchitis are not established, though some studies show promising results. Future controlled well-designed studies are warranted.
\end{abstract}

Keywords: pouchitis; fecal microbiota transplantation; microbiota; IPAA

\section{Introduction}

Restorative proctocolectomy with ileal pouch anal anastomosis (IPAA) is the surgical treatment in patients with ulcerative colitis (UC) refractory to medicinal therapy, in some cases of colorectal cancer and in familial adenomatous polyposis [1]. However, pouchitis occurs in up to $60 \%$ of the UC patients after surgery [2,3]. Pouchitis is characterized by inflammation, mainly confined to the pouch, with symptoms such as increased bowel movements, fever, bloody stool, fatigue, and abdominal pain $[2,4]$. Pouchitis often develops as an acute, but transient, inflammation responding to antibiotics. For $5 \%$ of patients, the inflammation becomes chronic, being antibiotic-dependent, with the need of continuously antibiotic treatment, or refractory, not responding to the standard treatment with antibiotics [5-7]. 
The etiology of pouchitis remains unclear, but the gut microbiome is hypothesized as a key factor. The pouch microbiome of patients with pouchitis is different compared to patients with a non-inflamed pouch [8,9]. The dysbiotic microbiome of an acute or chronic inflamed pouch is characterized by lowered bacterial diversity and changed abundance of certain bacteria $[8,10-12]$. Antibiotics can in many cases relieve symptoms of pouchitis and the use of probiotics can decrease the risk of developing pouchitis, further indicating the significance of the gut microbiome in pouchitis [12-14].

Pouchitis is usually treated with ciprofloxacin and/or metronidazole, which in case of chronic pouchitis often fails [15]. Treatment of chronic pouchitis is challenging with limited therapeutic options, potentially leading to the need for biological treatment or surgical removal of the ileal pouch [5-7].

Modification of the fecal microbiome in patients with chronic pouchitis has received increased attention within recent years [16]. The positive results of treating recurrent Clostridioides difficile infection (rCDI), with fecal microbiota transplantation (FMT) [17], and the promising results in inflammatory bowel disease (IBD) $[18,19]$, has led to the interest of inverting the gut dysbiosis of patients with chronic pouchitis using FMT to potentially relieve symptoms.

Within recent years, several smaller studies have reported both positive and negative clinical results of treating chronic pouchitis with FMT [20-23].

This systematic review aims to review the current literature on treatment of chronic pouchitis with FMT focusing on clinical effects, safety and the different approaches to FMT treatment.

\section{Methods}

\subsection{Search Strategy and Study Selection}

This systematic review was performed in accordance with the PRISMA 2009 guidelines [24]. A literature search was performed using Medline (from 1948), EMBASE (from 1947), and the Cochrane Central Register of Controlled Trials Library (for all years) through 15 April 2020. Bibliographies of review articles and meta-analyses were searched to identify additional studies $[8,25,26]$. Furthermore, the bibliography of the primary author of the included studies were reviewed to search for further eligible publications. Web of Science [27] was used to identify additional potential publications that have cited the included studies. Clinicaltrials.gov [28] and WHO International Clinical Trials Registry Platform [29] were used to search for results from unpublished studies. To search for grey literature opengrey.eu [30] was used. The detailed search strategy is outlined in the online Supplementary Materials, Table S1.

Eligibility criteria for inclusion of studies were defined prior to the search through registration of the research protocol in Prospero International Prospective Registry of Systematic Reviews (CRD42020167258) [31]. Inclusion criteria were "human interventional studies using FMT of all study types", including randomized controlled trials, non-randomized controlled studies, cohort studies, and case studies (case series and case reports), to "treat chronic pouchitis" (recurrent or antibiotic refractory) "reporting clinical outcomes on pouch symptoms". Studies including "participants of all ages" were included. The search was restricted to studies written in or translated to English. In controlled studies, the accepted comparator was either placebo, autologous FMT, or no treatment. Data presented as a conference abstract were also accepted. Exclusion criteria were studies where FMT was given as primary treatment to treat other conditions than chronic pouchitis.

All titles and abstracts from the literature search were screened for potential eligibility by two investigators (FC and SJK) independently, and in strict accordance with the inclusion and exclusion criteria. In case of dispute, the key decision was made by a third investigator (AMP).

\subsection{Data Management and Analysis}

Data extraction was performed independently by two investigators (FC and SJK). The following clinical information was extracted from each included study, if present: first author, year of publication, study location, study design, age and characteristics of study population, definition of condition under 
consideration including severity, details of intervention and methodology (such as dosage, frequency, route of administration, duration, and preparation of FMT material), primary and secondary outcome measures and results, duration of follow-up, change in the microbiome after FMT, registered adverse events (deaths, hospital admissions, and other adverse events as defined in each of the included studies), and donor characteristics.

The primary outcome was change in symptoms related to pouchitis compared to before FMT using the pouchitis disease activity index (PDAI) [32]. The definitions of clinical response (reduction in PDAI $\geq 3$ ) and clinical remission (reduction in PDAI $\geq 3$ and total PDAI of $<7$ ) were used to evaluate efficacy from studies reporting PDAI scores [7,33]. The use of the modified PDAI (mPDAI) and clinical PDAI (cPDAI) was accepted [34]. It was accepted that the evaluation of symptoms was performed at different timepoints after FMT.

Data was extracted as an intention-to-treat analysis, with dropouts assumed to be treatment failures. In case of missing data or need for further clarification, the corresponding author of the included study was contacted to retrieve further information. For the primary outcome of clinical response and remission, pooled estimates were calculated for all patients treated with FMT.

\subsection{Risk of Bias and Quality Assessment}

The Cochrane risk of bias tool was used to assess for bias in randomized controlled trials (RCTs) [35]. Risk of bias in the cohort and case studies was assessed using the US National Heart, Lung, and Blood Institute quality assessment tool [36], which has been used in other systematic reviews of FMT treatment [37], with four weeks selected as cut-off for appropriate follow-up. Further description of assessment of risk of bias and quality is available in the online Supplementary Materials, Tables S2-S4.

\section{Results}

The initial literature search identified 892 studies. After the removal of duplicates, 718 studies underwent title and abstract screening. A total of 49 studies were full-text reviewed for eligibility. Of these 40 were excluded for various reasons resulting in nine studies included in the qualitative and quantitative synthesis (Figure 1).

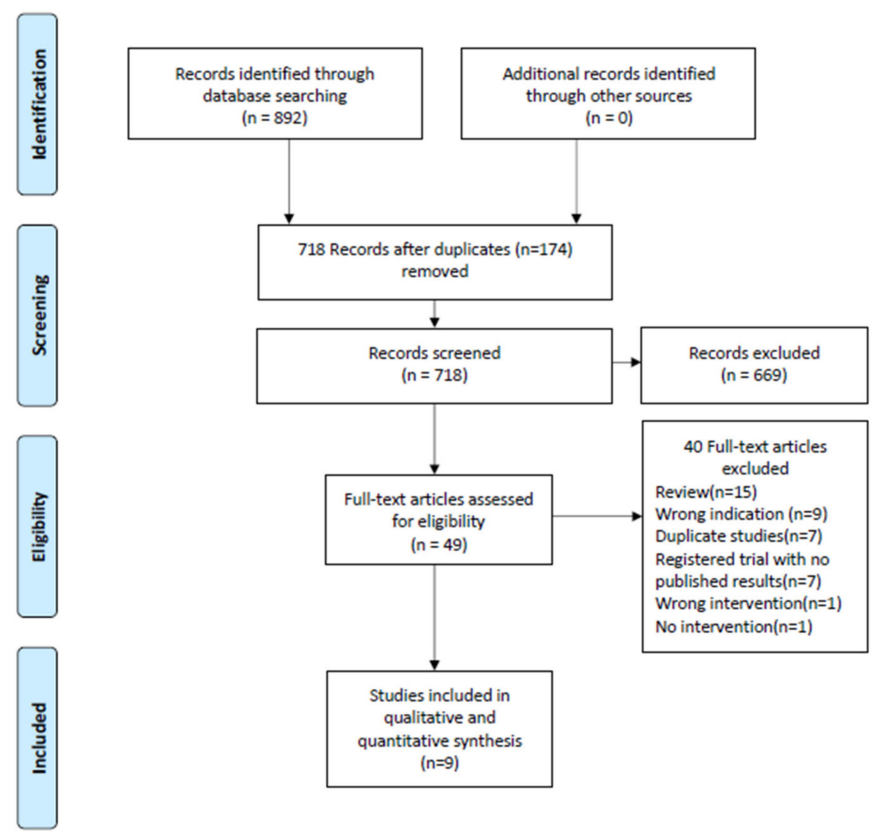

Figure 1. PRISMA flow diagram of assessment of studies identified in the systematic review of fecal microbiota transplantation (FMT) to treat chronic pouchitis. 


\subsection{Patient Characteristics and Study Types}

A total of 65 patients were treated with FMT in the nine included studies (Table 1). Most of the included studies were case series, case reports or pilot studies. Only one clinical trial by Herfarth et al. [23], randomized and blinded patients to receive either FMT or placebo. The definition of chronic pouchitis varied among studies with no consistency (Table 2). Some studies used certain values of PDAI $[33,38]$ or mPDAI prior to inclusion [23], while other focused on recurrent need for antibiotics (Table 2) [20,22,39].

Table 1. Patient characteristics, preparation of FMT and different treatment approaches of patients treated with FMT for chronic pouchitis.

\begin{tabular}{cc}
\hline Total number of studies, $n$ & 9 \\
\hline Total patient population, $n$ & 65 \\
\hline Mean days of FMT treatment, days (range) & $4.8(1-14)$ \\
\hline Mean delivered amount of stool by FMT, grams (range) $(n=51)$ & $111.8(11-525)$ \\
\hline Mean follow-up, days (range) $(n=65)$ & $87.6(28-365)$ \\
\hline Male/Female patients, $n(n=51)$ & $22 / 29$ \\
\hline Mean age of patients, years (range) $(n=51)$ & $43.8(22-77)$ \\
\hline Time since restorative proctocolectomy, mean years (range) $(n=50)$ & $10.3(1-33)$ \\
\hline Single/Multi donor FMT, $n(n=65)$ & $56 / 9$ \\
\hline Related/Unrelated donor, $n(n=65)$ & $12 / 53$ \\
\hline Upper/Lower administration/Both, $n(n=51)$ & $13 / 32 / 6$ \\
\hline Study type. Patients in RCT/Patients in non-RCT, $n(n=65)$ & $6 / 59$ \\
\hline
\end{tabular}

FMT, fecal microbiota transplantation; RCT, Randomized Clinical Trial; $n$, number. 
Table 2. Clinical effects of FMT treatment to patients with chronic pouchitis.

\begin{tabular}{|c|c|c|c|c|c|c|c|c|c|c|c|c|}
\hline $\begin{array}{l}\text { Author } \\
\text { and Year }\end{array}$ & $\begin{array}{l}\text { Study } \\
\text { Type }\end{array}$ & Patient Population & $\begin{array}{l}\text { Sample } \\
\text { Size }\end{array}$ & $\begin{array}{c}\text { FMT } \\
\text { Treatment }\end{array}$ & Route & Dosage & $\begin{array}{c}\text { Clinical } \\
\text { Response } \\
\text { (Reduction in } \\
\text { PDAI } \geq 3 \text { ) }\end{array}$ & $\begin{array}{c}\text { Clinical } \\
\text { Remission } \\
\text { (Reduction in } \\
\text { PDAI } \geq 3 \text { and } \\
\text { Total of }<7 \text { ) }\end{array}$ & $\begin{array}{l}\text { Endoscopic } \\
\text { Outcomes }\end{array}$ & $\begin{array}{l}\text { Histologic } \\
\text { Outcomes }\end{array}$ & Adverse Events & Follow-Up \\
\hline $\begin{array}{l}\text { Fang et al., } \\
2016\end{array}$ & $\begin{array}{l}\text { Case } \\
\text { report }\end{array}$ & $\begin{array}{l}\text { Chronic antibiotic } \\
\text { resistant pouchitis }\end{array}$ & 1 & Single FMT & $\begin{array}{l}\text { Sigmoidoscopy } \\
\text { (delivered } 40 \\
\text { cm into the } \\
\text { afferent limb } \\
\text { and pouch } \\
\text { body) }\end{array}$ & $\begin{array}{l}\text { Stool mixed } \\
\text { with saline and } \\
\text { diluted to } \\
250 \mathrm{~mL}\end{array}$ & $\begin{array}{c}1 / 1 \text { after } 3 \\
\text { months (cPDAI } \\
\text { decreased from } \\
6 \text { at baseline } \\
\text { to } 0)\end{array}$ & $\begin{array}{c}1 / 1 \text { after } 3 \\
\text { months (cPDAI } \\
\text { decreased from } \\
6 \text { at baseline } \\
\text { to } 0 \text { ) }\end{array}$ & NA & NA & $\begin{array}{l}\text { No reported } \\
\text { adverse events. }\end{array}$ & 3 months \\
\hline $\begin{array}{c}\text { Herfarth } \\
\text { et al., } 2019\end{array}$ & $\begin{array}{l}\text { RCT with } \\
\text { open-label } \\
\text { follow-up }\end{array}$ & $\begin{array}{c}\text { Chronic antibiotic } \\
\text { dependent } \\
\text { pouchitis }>4 \text { weeks. } \\
\text { mPDAI } \geq 5\end{array}$ & $\begin{array}{l}6 \text { (FMT (4) } \\
\text { Placebo } \\
(2)) . \\
5 \text { received } \\
\text { open-label } \\
\text { FMT } \\
\text { afterwards }\end{array}$ & $\begin{array}{c}\text { Single } \\
\text { endoscopic } \\
\text { FMT followed } \\
\text { by daily oral } \\
\text { encapsulated } \\
\text { FMT for } \\
2 \text { weeks }\end{array}$ & $\begin{array}{l}\text { Sigmoidoscopy } \\
\text { and oral } \\
\text { capsules }\end{array}$ & $\begin{array}{c}\text { eFMT } \\
(2 \times 30 \mathrm{~mL} \\
\text { total of } 24 \mathrm{~g} \\
\text { donor stool }) \\
\text { and } 6 \text { capsules } \\
\text { daily consisting } \\
\text { of } 4.2 \mathrm{~g} \\
\text { donor stool }\end{array}$ & $\begin{array}{c}1 / 6 \text { (Four } \\
\text { patients } \\
\text { receiving } \\
\text { primary FMT } \\
\text { and two } \\
\text { patients } \\
\text { receiving } \\
\text { open-label FMT } \\
\text { included) }\end{array}$ & $\begin{array}{l}\text { 1/6 (clinical } \\
\text { PDAI } 1 \text { and no } \\
\text { need for } \\
\text { antibiotics) }\end{array}$ & NA & $\mathrm{NA}$ & $\begin{array}{l}\text { No FMT related } \\
\text { safety events } \\
\text { were observed. }\end{array}$ & 16 weeks \\
\hline $\begin{array}{l}\text { Kousgaard } \\
\text { et al., } 2020\end{array}$ & $\begin{array}{l}\text { Cohort } \\
\text { (open-label } \\
\text { pilot } \\
\text { study) }\end{array}$ & $\begin{array}{l}\text { Chronic pouchitis } \\
\text { ( } \geq 3 \text { episodes of } \\
\text { pouchitis within } \\
\text { the last year) }\end{array}$ & 9 & $\begin{array}{l}14 \text { days of daily } \\
\text { self-administered } \\
\text { FMT }\end{array}$ & Enema & $\begin{array}{c}20 \mathrm{~g} \text { fecal } \\
\text { material diluted } \\
\text { in } 100 \mathrm{~mL} \text { saline }\end{array}$ & $\begin{array}{l}\text { 3/9 after four } \\
\text { weeks }\end{array}$ & $\begin{array}{l}\text { 3/9 after four } \\
\text { weeks }\end{array}$ & $\begin{array}{l}\text { Mean ePDAI of } \\
3.2 \text { at baseline } \\
\text { decreased to } 2.2 \\
\text { after four weeks }\end{array}$ & $\begin{array}{l}\text { Mean hPDAI of } \\
1.7 \text { decreased to } \\
1.0 \text { after four } \\
\text { weeks }\end{array}$ & $\begin{array}{l}\text { 7/9 patients } \\
\text { reported adverse } \\
\text { events while } \\
\text { treated. } \\
\text { Abdominal } \\
\text { pain (5), } \\
\text { uncomfortable } \\
\text { (2), nausea (2), } \\
\text { fever (2), bloating } \\
\text { (1), dizziness (1), } \\
\text { and fatigue (1). }\end{array}$ & 6 months \\
\hline $\begin{array}{l}\text { Landy } \\
\text { et al., } 2015\end{array}$ & $\begin{array}{l}\text { Cohort } \\
\text { (pilot } \\
\text { study) }\end{array}$ & $\begin{array}{l}\text { Chronic pouchitis } \\
\text { with current } \\
\text { PDAI } \geq 7\end{array}$ & 8 & Single FMT & Nasogastric & $\begin{array}{l}30 \mathrm{~mL} \text { of } \\
\text { fecal-saline } \\
\text { solution } \\
\text { followed by } \\
50 \mathrm{~mL} \text { saline }\end{array}$ & $\begin{array}{l}2 / 8 \text { after } \\
4 \text { weeks }\end{array}$ & $\begin{array}{l}0 / 8 \text { after } \\
4 \text { weeks }\end{array}$ & $\begin{array}{c}\text { Mean ePDAI of } \\
5 \text { at both } \\
\text { baseline and } \\
\text { after } 4 \text { weeks }\end{array}$ & $\begin{array}{l}\text { Mean hPDAI of } \\
3 \text { at baseline } \\
\text { decreased to } 2 \\
\text { after four weeks }\end{array}$ & $\begin{array}{c}\text { Nausea (3), } \\
\text { bloating (2), } \\
\text { vomiting (1), } \\
\text { fever (1). All } \\
\text { transient (<24 h). }\end{array}$ & 4 weeks \\
\hline $\begin{array}{l}\text { Nishida } \\
\text { et al., } 2019\end{array}$ & $\begin{array}{l}\text { Case } \\
\text { series }\end{array}$ & $\begin{array}{l}\text { Chronic pouchitis } \\
\text { with current } \\
\text { PDAI } \geq 7\end{array}$ & 3 & Single FMT & Colonoscopy & $\begin{array}{l}150-200 \mathrm{~g} \\
\text { donor stool } \\
\text { mixed with } \\
350-500 \mathrm{~mL} \\
\text { sterile saline }\end{array}$ & $\begin{array}{c}1 / 3 \text { after } 8 \\
\text { weeks }\end{array}$ & $\begin{array}{l}0 / 3 \text { after } 8 \\
\text { weeks }\end{array}$ & NA & NA & $\begin{array}{l}\text { No reported } \\
\text { adverse events. }\end{array}$ & 8 weeks \\
\hline $\begin{array}{l}\text { Schmid } \\
\text { et al., } 2017\end{array}$ & $\begin{array}{l}\text { Case } \\
\text { report }\end{array}$ & $\begin{array}{c}\text { A severe flare of } \\
\text { pouchitis in a } \\
\text { patient diagnosed } \\
\text { with pouchitis one } \\
\text { year earlier }\end{array}$ & 1 & $\begin{array}{l}\text { A total of three } \\
\text { FMTs at } \\
\text { baseline, after } 5 \\
\text { and } 9 \text { weeks }\end{array}$ & Pouchoscopy & $\begin{array}{c}250 \mathrm{~mL} \\
\text { fecal-saline } \\
\text { suspension }\end{array}$ & $\begin{array}{l}\text { 0/1 after } 9 \\
\text { weeks }\end{array}$ & $\begin{array}{c}0 / 1 \text { after } 9 \\
\text { weeks }\end{array}$ & NA & NA & $\begin{array}{l}\text { No reported } \\
\text { adverse events. }\end{array}$ & 9 weeks \\
\hline
\end{tabular}


Table 2. Cont.

\begin{tabular}{|c|c|c|c|c|c|c|c|c|c|c|c|c|}
\hline $\begin{array}{l}\text { Author } \\
\text { and Year }\end{array}$ & $\begin{array}{l}\text { Study } \\
\text { Type }\end{array}$ & Patient Population & $\begin{array}{l}\text { Sample } \\
\text { Size }\end{array}$ & $\begin{array}{c}\text { FMT } \\
\text { Treatment }\end{array}$ & Route & Dosage & $\begin{array}{l}\text { Clinical } \\
\text { Response } \\
\text { (Reduction in } \\
\text { PDAI } \geq 3 \text { ) }\end{array}$ & $\begin{array}{c}\text { Clinical } \\
\text { Remission } \\
\text { (Reduction in } \\
\text { PDAI } \geq 3 \text { and } \\
\text { Total of }<7 \text { ) }\end{array}$ & $\begin{array}{l}\text { Endoscopic } \\
\text { Outcomes }\end{array}$ & $\begin{array}{l}\text { Histologic } \\
\text { Outcomes }\end{array}$ & Adverse Events & Follow-Up \\
\hline $\begin{array}{l}\text { Selvig } \\
\text { et al., } 2020\end{array}$ & $\begin{array}{l}\text { Cohort } \\
\text { (prospective } \\
\text { open-label } \\
\text { pilot } \\
\text { study) }\end{array}$ & $\begin{array}{l}\text { Chronic pouchitis. } \\
\text { Prior endoscopic } \\
\text { evaluation } \\
\text { confirming } \\
\text { inflammation and } \\
\text { over } 4 \text { weeks of } \\
\text { symptoms }\end{array}$ & $\begin{array}{l}18(7 \text { of } \\
\text { the } \\
18 \text { patients } \\
\text { pre-treated } \\
\text { with } \\
\text { Rifaximin })\end{array}$ & $\begin{array}{l}1 \text { or } 2 \text { FMTs. } \\
\text { Single or } \\
\text { optional } \\
\text { re-treatment }\end{array}$ & $\begin{array}{l}\text { Pouchoscopy. } \\
\text { Delivered to the } \\
\text { most proximal } \\
\text { point of } \\
\text { insertion } \\
\text { (proximal } \\
\text { pouch or } \\
\text { neo-terminal } \\
\text { ileum) }\end{array}$ & $\begin{array}{l}250 / 500 \mathrm{~mL} \text { in } \\
\text { total derived } \\
\text { from } 25 / 50 \mathrm{~g} \\
\text { stool }\end{array}$ & $\begin{array}{c}1 / 11 \text { after } 4 \\
\text { weeks. Only } 11 \\
\text { underwent } \\
\text { pouchoscopy at } \\
4 \text { weeks }\end{array}$ & $\begin{array}{c}\text { 1/11 after } 4 \\
\text { weeks }\end{array}$ & $\begin{array}{c}\text { Mean ePDAI of } \\
3.38 \text { at baseline } \\
\text { decreased to } \\
3.36 \text { after four } \\
\text { weeks }\end{array}$ & $\begin{array}{c}\text { Mean hPDAI of } \\
1.05 \text { at baseline } \\
\text { increased to } \\
1.36 \text { after four } \\
\text { weeks }\end{array}$ & $\begin{array}{c}\text { One patient } \\
\text { admitted to } \\
\text { hospital } 8 \text { days } \\
\text { after FMT } \\
\text { because of } \\
\text { abdominal pain } \\
\text { considered not } \\
\text { related to FMT. } \\
\text { One patient } \\
\text { diagnosed with } \\
\text { Crohn's disease } \\
\text { at pouchoscopy } \\
\text { after four weeks, } \\
\text { which was } \\
\text { suspected in } \\
\text { advance. Minor } \\
\text { self-limiting } \\
\text { adverse events. } \\
\text { Discomfort (4), } \\
\text { flatulence (4), } \\
\text { bloating or } \\
\text { cramping (3), } \\
\text { fatigue (3), and } \\
\text { nausea (2). }\end{array}$ & 12 months \\
\hline $\begin{array}{l}\text { Stallmach } \\
\text { et al., } 2016\end{array}$ & $\begin{array}{l}\text { Prospective } \\
\text { open-label } \\
\text { pilot } \\
\text { study }\end{array}$ & $\begin{array}{l}\text { Chronic antibiotics } \\
\text { resistant pouchitis } \\
\text { (three or more } \\
\text { cycles of } \\
\text { antibiotics) }\end{array}$ & 5 & 1-7 FMTs & $\begin{array}{l}\text { FMT to the } \\
\text { jejunum with } \\
\text { intervals of } \\
3-4 \text { weeks }\end{array}$ & $\begin{array}{l}275 \mathrm{~mL} \text { fecal } \\
\text { saline } \\
\text { suspension } \\
\text { derived from } \\
75 \mathrm{~g} \text { stool }\end{array}$ & $\begin{array}{l}\text { 5/5 after last } \\
\text { FMT. }\end{array}$ & $\begin{array}{l}\text { 4/5 after last } \\
\text { FMT }\end{array}$ & $\begin{array}{l}\text { Mean ePDAI of } \\
3.8 \text { at baseline } \\
\text { decreased to } 1.2 \\
\text { after last FMT }\end{array}$ & $\begin{array}{l}\text { Mean hPDAI of } \\
3 \text { at baseline } \\
\text { decreased to } 1.2 \\
\text { after last FMT }\end{array}$ & $\begin{array}{l}\text { Mild transient } \\
\text { fever and CRP } \\
\text { increase in one } \\
\text { patient. }\end{array}$ & $\begin{array}{l}3 \text { months. } \\
\text { One patient } \\
\text { followed for } \\
12 \text { months }\end{array}$ \\
\hline $\begin{array}{l}\text { Steube } \\
\text { et al., } 2017\end{array}$ & $\begin{array}{l}\text { Prospective } \\
\text { open-label } \\
\text { pilot } \\
\text { study }\end{array}$ & $\begin{array}{l}\text { Chronic antibiotics } \\
\text { resistant pouchitis }\end{array}$ & 14 & 2-4 FMTs & $\begin{array}{l}\text { Nasojejunal or } \\
\text { capsule } \\
\text { application } \\
\text { delivered every } \\
4 \text { weeks } \\
\text { according to } \\
\text { treatment } \\
\text { outcome }\end{array}$ & NA & $\begin{array}{l}\text { 7/14. PDAI } \\
\text { scores however } \\
\text { not described. } \\
\text { Assessed } \\
\text { through } \\
\text { F-Calprotectin. }\end{array}$ & NA & NA & NA & $\begin{array}{c}\text { No reported } \\
\text { adverse events. }\end{array}$ & 8 weeks \\
\hline
\end{tabular}

FMT, Fecal Microbiota Transplantation; RCT, Randomized Controlled Trial; mPDAI, modified Pouchitis Disease Activity Index; F-Calprotectin, Fecal Calprotectin. 


\subsection{Clinical Effects of FMT Treatment}

The only included RCT, by Herfarth et al. [23], was prematurely stopped because of lower than expected clinical remission rate and low donor engraftment. All of the four FMT treated patients and the two placebo treated patients enrolled failed to respond and needed antibiotic rescue therapy after study treatment. One patient (primarily receiving placebo) of the five patients treated in the following open-label FMT extension phase achieved antibiotic free clinical remission.

The nine included studies did not evaluate the clinical effect of FMT at the same timepoint or used the same methods to evaluate disease activity, why it was not possible to perform a proper meta-analysis. One study did not evaluate treatment response through PDAI in all patients [40] and one study used Fecal Calprotectin (F-Calprotectin) [20]. Hence, pooled estimates of the primary endpoints of clinical response and remission could only be evaluated in 44 patients. Clinical response was achieved in $14(31.8 \%)$ out of 44 evaluated patients at various timepoints after FMT treatment, while clinical remission was achieved in $10(22.7 \%)$ out of 44 evaluated patients at various timepoints after FMT.

Four of the included studies reported endoscopic and histologic PDAI (ePDAI and hPDAI) with a trend of small improvements in two of the studies [22,39], while no change or minor beneficial changes were observed in the other two (Table 2) $[38,40]$.

Some studies also evaluated specific symptoms. Selvig et al. [40], reported improvement in number of bowel movements and abdominal pain, while Schmid et al. [21], reported transiently improved bloating and pain with stool urgency and frequency remaining grossly unchanged.

F-Calprotectin is routinely used as a marker of disease activity in patients with IBD and pouchitis and is found to be correlated to change in symptoms [41]. In the studies where the patients' symptoms/ PDAI improved, F-Calprotectin also decreased [20,22]. F-Calprotectin was stable or decreased insignificantly in the studies finding no or minor beneficial effects after treatment [23,40].

\subsection{Safety/Adverse Events}

No deaths, hospital admissions or serious adverse events considered related to FMT were reported. Minor self-limiting adverse events were reported in several studies [22,38-40]. Most of these were gastrointestinal (nausea, abdominal pain, or bloating), but fever, dizziness, fatigue and feeling uncomfortable were also reported (Table 2).

\subsection{Microbiome Changes after FMT}

Six studies assessed if bacterial alpha diversity increased in fecal or mucosal samples after FMT treatment. In five studies, no significant changes were observed [23,33,38-40]. This was true in studies using both single and multiple FMT treatments [33,38-40]. In the study by Herfarth et al., increased fecal bacterial diversity after FMT was concluded to be mainly caused by the cessation of antibiotic treatment $24 \mathrm{~h}$ prior to FMT [23]. Steube et al., found a significant increased bacterial alpha diversity in patients with improved clinical outcomes after FMT treatment [20]. However, an increased bacterial alpha diversity was not necessarily correlated to improved clinical outcomes, and some patients increased their diversity without clinical improvement.

Seven studies analysed whether the recipients' microbiota resembled the donors' microbiota after treatment $[20,22,23,33,38-40]$. Interestingly, increased resemblance to the donors' microbiota after treatment was in three studies correlated to beneficial clinical effect with significant changes seen only in patient who improved clinically $[22,23,40]$.

Four studies reported changed abundance of certain specific bacteria after FMT [20,22,38,40]. Species such as Ruminococcaceae and Lachnospiraceae family and genus Faecaelibacterium were enriched as sign of engraftment and others such as Escherichia coli decreased in abundance in recipients after FMT treatment. None of these studies reported a correlation to clinical effect of engraftment or decreased abundance of specific bacteria. 


\subsection{Preparation and Delivery of FMT Material}

Most of the included studies used FMT material from unrelated donors $[20,22,23,38,40]$, but in three studies FMT material from relatives were used (Table 3) $[21,33,38]$. Only the study by Kousgaard et al., used FMT from multiple donors [39]. The delivered FMT material varied greatly in the preparation method and delivery approach among the included studies (Table 3). Five studies used fresh fecal material delivered $4-6 \mathrm{~h}$ prior to treatment $[21,22,33,38]$, while other used frozen material $[22,23,39,40]$. The FMT material was delivered to the recipients through both upper $[20,22,38]$ and lower endoscopically delivery [21,23,33,40,42], and delivery through capsules [20,23], or enemas [39] (Table 2). The use of different types of bowel cleansing prior to FMT was reported in several of the studies delivering FMT through lower endoscopy [21,33,40].

The length of FMT treatment also varied between the studies from a single FMT [33,38,42], to up to two weeks of daily treatment $[23,39]$. Hence, the total delivered FMT dose varied in between the studies. The lowest amount of $30 \mathrm{~mL}$ fecal-saline solution was reported in the study by, Landy et al. [38], and the highest amount of a total of $1925 \mathrm{~mL}$ FMT material derived from $525 \mathrm{~g}$ stool delivered to one of the patients during seven FMTs was reported in the study by Stallmach et al. [22].

Two studies reported stopping antibiotic treatment $24-48 \mathrm{~h}$ prior to FMT treatment [23,42], while seven of the 18 patients in the study by Selvig et al. [40] were pre-treated with rifaximin for a total of five days, beginning eight days prior to FMT. The patients in the included studies were in general permitted to continue concomitant treatment while receiving FMT including biological treatment, [40] while antibiotics and probiotics were not permitted [39,42].

\subsection{Quality Assessment of Studies and Risk Of Bias}

Six studies were rated as having fair to poor quality due to high risk of bias and small sample size. Only one RCT, by Herfarth et al. [23], with six included patients was included. Most of the other studies were case series and case reports with no predefined treatment outcomes or inclusion criteria (online Supplementary Materials, Tables S2-S4). 
Table 3. Preparation and delivery of FMT material.

\begin{tabular}{|c|c|c|c|c|c|c|c|}
\hline Author and Year & Donor(s) & Fresh/Frozen & FMT Preparation & Concomitant Treatment & $\begin{array}{l}\text { Pre-Treatment } \\
\text { with Antibiotics }\end{array}$ & Single/Multi-donor & Bowel Cleansing \\
\hline Fang et al., 2016 & Unrelated donor & Fresh & $\begin{array}{l}\text { Stool mixed with sterile saline and } \\
\text { diluted to } 250 \mathrm{~mL}\end{array}$ & $\begin{array}{l}\text { The patient was off his usual } \\
\text { antibiotics during the entire } \\
\text { follow-up period but } \\
\text { continued antidiarrheal } \\
\text { medication. }\end{array}$ & $\begin{array}{l}\text { Antibiotics } \\
\text { stopped } 48 \mathrm{~h} \\
\text { before FMT }\end{array}$ & Single & No \\
\hline Herfarth et al., 2019 & $\begin{array}{l}\text { Unrelated donor with } \\
\text { high butyrate } \\
\text { production }\end{array}$ & Frozen & $\begin{array}{l}\text { Stool bank provided FMT for } \\
\text { endoscopic administration, FMT } \\
\text { capsules and matching placebos }\end{array}$ & NA & $\begin{array}{l}\text { Antibiotics } \\
\text { stopped } 24 \mathrm{~h} \\
\text { before FMT }\end{array}$ & Single & NA \\
\hline Kousgaard et al., 2020 & Unrelated & Frozen & $\begin{array}{c}20 \mathrm{~g} \text { stool mixed with } 100 \mathrm{~mL} \\
\text { sterile water, blended and filtered, } \\
10 \% \text { glycerol }\end{array}$ & $\begin{array}{l}\text { Concurrent therapies were } \\
\text { permitted if stable with } \\
\text { exception of antibiotics, } \\
\text { probiotics, and biologic } \\
\text { treatment. }\end{array}$ & $\begin{array}{l}\text { Antibiotics } \\
\text { stopped } 7 \text { days } \\
\text { before FMT }\end{array}$ & $\begin{array}{l}\text { Multi-donor (5 } \\
\text { donors) }\end{array}$ & No \\
\hline Landy et al., 2015 & $\begin{array}{l}\text { Relative/partner (6) or } \\
\text { anonymous (2) }\end{array}$ & $\begin{array}{l}\text { Fresh (less than } 6 \mathrm{~h} \\
\text { prior to FMT) }\end{array}$ & $\begin{array}{l}30 \mathrm{~g} \text { of stool was homogenized } \\
\text { with a household blender in } 50 \mathrm{~mL} \\
\text { of } 0.9 \% \text { saline and filtered through } \\
\text { sterile gauze to produce a } \\
\text { fecal-saline solution }\end{array}$ & $\begin{array}{l}\text { Night before the procedure } \\
\text { the recipient was treated with } \\
\text { a proton pump inhibitor } \\
\text { (Omeprazole } 20 \mathrm{mg} \text { ). }\end{array}$ & NA & Single & NA \\
\hline Nishida et al., 2019 & $\begin{array}{l}\text { Second degree } \\
\text { relatives }\end{array}$ & $\begin{array}{l}\text { Fresh (less than } 4 \mathrm{~h} \\
\text { prior to FMT) }\end{array}$ & $\begin{array}{l}150-200 \mathrm{~g} \text { donor stool mixed with } \\
350-500 \mathrm{~mL} \text { sterile saline and } \\
\text { filtered through gaze }\end{array}$ & NA & NA & Single & $\begin{array}{l}\text { Polyethylene glycol } \\
\text { solution }\end{array}$ \\
\hline Schmid et al., 2017 & Patient's son & $\begin{array}{l}\text { Fresh (less than } 6 \mathrm{~h} \\
\text { prior to FMT) }\end{array}$ & $\begin{array}{l}\text { A fresh stool sample diluted with } \\
500 \mathrm{~mL} \text { saline and filtered } \\
\text { through gaze }\end{array}$ & NA & NA & Single & Enemas \\
\hline Selvig et al., 2020 & Unrelated & Frozen & $\begin{array}{l}25 \mathrm{~g} \text { of stool mixed with saline to a } \\
250 \mathrm{~mL} \text { fecal suspension }\end{array}$ & $\begin{array}{l}\text { Accepted with antibiotics as } \\
\text { exception. Three patients } \\
\text { continued biologic treatment. }\end{array}$ & $\begin{array}{l}\text { 7/18 patients } \\
\text { received } 5 \text { days of } \\
550 \text { mg Rifaximin } \\
\text { beginning } 8 \text { days } \\
\text { prior to treatment }\end{array}$ & $\begin{array}{c}\text { Single (from } 11 \\
\text { different donors) }\end{array}$ & $\begin{array}{l}\text { Magnesium citrate a day } \\
\text { before FMT and } \\
\text { phosphate enema at day } \\
\text { of FMT }\end{array}$ \\
\hline Stallmach et al., 2016 & Unrelated & $\begin{array}{l}\text { Fresh (first FMT) } \\
\text { and frozen }\end{array}$ & $\begin{array}{l}150 \mathrm{~g} \text { stool mixed with } 400 \mathrm{~mL} \\
\text { saline. Then filtered and separated } \\
\text { in two. The first immediately } \\
\text { delivered to the patient and the } \\
\text { second stored at }-80^{\circ} \mathrm{C}\end{array}$ & NA & NA & $\begin{array}{l}\text { Single (from } 2 \\
\text { different donors) }\end{array}$ & No \\
\hline Steube et al., 2017 & Unrelated & NA & NA & NA & NA & $\begin{array}{c}\text { Single (from } 3 \\
\text { different donors) }\end{array}$ & NA \\
\hline
\end{tabular}

NA, not available; FMT, Fecal Microbiota Transplantation. 


\section{Discussion}

\subsection{Main Findings}

Only nine studies have investigated the effects of FMT on pouchitis symptoms in a total of 65 patients with chronic pouchitis. There is a scarceness of high-quality studies; hence, the true effect of the treatment remains unclear. The only RCT included in this systematic review [23], was prematurely stopped because of low clinical efficacy and low donor microbial engraftment. Some of the included studies reported high response and remission rates [20,22], while others found no or minor beneficial effect of the treatment $[21,23,38,40]$. The calculated proportions of patients achieving clinical response and remission of $31.8 \%$ and $22.7 \%$, respectively, must be interpreted with precaution since a great heterogeneity between the studies exist and the low quality of evidence in most studies. Hence, this systematic review gives no clear answers of whether FMT is beneficial in patients with chronic pouchitis, but points towards the need for new well-designed controlled studies.

\subsection{Strengths and Limitations}

This systematic review is the first to collect data on clinical outcomes from all published studies treating chronic pouchitis patients with FMT. A systematic review on this topic is important, as studies on FMT to chronic pouchitis only have included a very limited number of patients each. The review gives the first full overview of both the clinical indications of treatment, the different treatment approaches, the clinical efficacy, safety of treatment and microbiome changes caused by the treatment.

There are also limitations. The quality of evidence in most of the included studies were evaluated as fair or poor, and only one RCT was included. Furthermore, there was great differences in definition of disease activity both prior to and after treatment. The timepoint where the effect of treatment was assessed also varied among studies. Further, all included studies had different approaches to preparation, delivery and length of FMT treatment, which make interpretation of the overall effects and approaches of treatment very difficult.

\subsection{Clinical Efficacy of Treatment}

Some of the included studies found improved clinical outcomes with decreased symptom scores [22,39], and lowered F-Calprotectin [20], which indicate that some patients with chronic pouchitis may benefit from treatment with FMT. Furthermore, Lan et al. reported potential beneficial effects of FMT for treating Clostridioides difficile infection in patients with ileal pouches [43]. The authors reported that FMT treatment of rCDI in patient with ileal pouches, also improved pouchitis symptoms besides the elimination of rCDI symptoms. A further indication of a potential beneficial effect is the finding of a correlation between engraftment of donor microbiome and improved clinical outcomes in the recipients, reported in several of the studies included in the review $[20,22,23,40]$. Several studies found a missing or low clinical efficacy in the majority of the patients $[21,23,38,40]$, indicating that not all patients might benefit from the FMT treatment or that the treatment should be delivered differently.

In UC, where gut dysbiosis also has been linked to disease activity [44], FMT treatment has been found superior to placebo treatment in recent RCTs, although the treatment protocols varied in between the studies [18,45-47]. The pooled clinical response and remission rates of the RCTs of $49 \%$ and $28 \%$, respectively [48], also indicate that not all UC patients benefit from the treatment. The focus is now to predict which patients that may benefit from FMT treatment in both UC and other conditions [49,50].

The general definition of chronic pouchitis is confirmed pouchitis by PDAI with more than four weeks disease activity [7]. In this review, we choose to get a full overview of the FMT treatment and treatment indications. Hence, we included both studies that used antibiotic refractory/dependent pouchitis and several episodes of pouchitis within the last year as inclusion criteria. This makes it almost impossible to transfer conclusions regarding treatment efficacy to all patients with chronic pouchitis. Furthermore, not all studies evaluated the patients with a full PDAI score [20,23,42]. The PDAI score is an 18-point index to assess pouchitis activity, based on clinical symptoms, endoscopically 
and histologically evaluation and is the most commonly used tool to evaluate pouchitis disease activity [7,51]. The use of the modified scores mPDAI [34] (only including clinical symptoms and endoscopic evaluation) and cPDAI (only including clinical symptoms), makes it easier to include patients in studies because endoscopies and biopsies are not needed, but decreases the comparability of the results. Therefore, we urge that future studies use a full PDAI score before and after treatment with FMT. We also recommend that the commonly used definitions of clinical response (reduction in PDAI $\geq 3$ ) and remission (reduction in PDAI $\geq 3$ and PDAI of $<7$ ) are used in future studies [7].

Further we recommend that evaluation of the patients should be after four weeks, since a beneficial clinical effect of FMT treatment has been reported at this timepoint in several of the included studies $[38,39,52]$.

\subsection{Safety}

Only self-limiting transient mainly gastrointestinal adverse events were reported as related to FMT in the included studies, which are in line with data from FMT treatment to other indications $[53,54]$. In general, FMT treatment is considered safe, when the current international recommendations considering donor screening are followed [53,55]. A recent death of an immunocompromised patients announced in June 2019, by the Federal Drug Agency (FDA) in the Unites States, following treatment with FMT capsules, where extended-spectrum beta-lactamase (ESBL)-producing Escherichia coli were transferred from the donor to the recipient, indicates that donor screening protocols must be elaborate to avoid the transfer of multi-drug resistant microorganisms [56]. No cases of transferred diseases were reported in any of the included studies. The long-term safety of FMT is not fully investigated. Results from patients with rCDI treated with FMT, which are often multi-morbid and frail, does not indicate long-term adverse events [54,57]. FMT to chronic pouchitis possibly requires several FMT treatments to achieve clinical remission similar to UC $[18,45,46,48,58]$, whereas usually one FMT is sufficient to treat rCDI [59]. It is therefore of great importance that future studies investigate the long-term adverse events after FMT to patients with chronic pouchitis.

\subsection{Microbiome Changes}

Whether the changed gut microbiome of patients with chronic pouchitis is a cause or a consequence of the disease is not fully understood [8]. Furthermore, patients with chronic pouchitis often have received several antibiotic treatments, which also changes the microbiota of the pouch [12]. The results from some of the included studies using $16 \mathrm{~S}$ sequencing indicate that there is a correlation between improved clinical outcomes and changes in the gut microbiome with increased bacterial alpha diversity or increased resemblance to the healthy donor microbiota after FMT $[20,22,23,40]$, while Herfarth et al. [23], terminated their RCT because of low clinical efficacy and low donor engraftment.

In cases of treating rCDI and inducing clinical remission in UC the following microbiome changes have been correlated to success of treatment after FMT; increased bacterial diversity [60], increased resemblance of the recipients microbiome to the donors [46], and changes in the amount of certain potentially harmful or beneficial bacteria [61]. Hence, it makes sense to design FMT interventions in doses appropriate for such microbiome changes in future trials of chronic pouchitis.

The role of other parts of the gut microbiome than bacteria in chronic pouchitis has not been reported [8]. Knowledge from other diseases indicates the important roles of fungi and bacteriophages in correlation to the effect of FMT [62,63]. Thus, future trials investigating the effect of FMT on other parts of the gut microbiome are important to increase the understanding of the correlation between the microbiome and chronic pouchitis. Furthermore, none of the included studies used next-generation sequencing techniques, such as shotgun metagenomics [64], which are being increasingly used in the evaluation of the effects of FMT in the treatment of other conditions [65]. We recommend future studies to use deeper microbiome analysis, not limited to $16 \mathrm{~S}$ sequencing, to advance our understanding of the changes in the microbiome caused by FMT. 


\subsection{FMT Material: Donors}

Results from studies using FMT treatment to UC and irritable bowel syndrome (IBS) have indicated that certain donors are more "superior" than others to induce beneficial clinical effects in patients $[46,49,66]$. The gut dysbiosis of chronic pouchitis is probably different from the gut dysbiosis associated to other conditions: hence, a good donor in treatment of chronic pouchitis may be different than for other conditions [8]. Neither in chronic pouchitis or other diseases there is a full understanding of what defines an ideal donor, though the understanding is increasing [60].

In the included RCT by Herfarth et al. [23], which found no beneficial effect of FMT, a donor delivering stools with a high butyrate content was used. Butyrate has been correlated to high microbial diversity and better therapeutic response in FMT trials treating other conditions [67-70]. Three of the included studies used a close relative as stool donor $[21,33,38]$, which is not considered inferior, but with the establishment of stool banks, treatment with stool from close relatives will probably become less prevalent [71]. Patients with a pouch without episodes of pouchitis possibly have a healthy microbiome preventing pouchitis and could maybe be ideal donors.

We encourage future studies to continue the assessment of whether certain characteristics of the donor microbiome are associated with beneficial effects.

\subsection{FMT Material: Preparation and Delivery}

In general, the included studies varied in both the preparation of FMT material, amount of stool used for treatment, and whether the treatment was given shortly after donation or if frozen stored FMT material was used. In the treatment of UC and IBS, where a dysbiotic gut microbiome probably should be changed to a eubiotic through engraftment of beneficial microorganisms from healthy donors, higher doses or multiple deliveries are more effective than lower doses or single FMT treatment $[48,66]$. We propose future trials to use multiple FMT treatment based upon this knowledge.

\subsection{FMT Material: Route of Administration}

In spite of the anatomic location of the diseased tissue in the lower gastrointestinal tract of chronic pouchitis, several of the included studies used upper administration of FMT material through either capsules [20,23], or upper endoscopy [20,22]. The fact that some of these studies found positive clinical effects indicate that both upper and lower administration may have beneficial effect. For other conditions located in the lower part of the gastrointestinal tract, such as IBS and UC, a treatment with FMT delivered through upper administration has also been found successful [72,73]. Future studies should investigate if a certain route is more beneficial than others.

\subsection{Perspectives}

As FMT treatment has received a more widespread use and the establishment of stool banks are emerging in many countries [74,75], we hope that more well-designed controlled trials investigating the effects of FMT in chronic pouchitis will be performed. This in spite of the disappointing clinical results from the only RCT published by Herfarth et al. in 2019 [23], possibly due to low donor microbial engraftment. Chronic pouchitis patients have severely impaired health related quality of life [76], and there is strong need of new treatment options. Future well-designed controlled trials using clearly defined disease definitions, comparing the effects of FMT treatment with either placebo, FMT delivered through another route or FMT with a different dose or duration, will be necessary to move the understanding of the true effect of FMT treatment in chronic pouchitis forward.

\section{Conclusions}

The effects of fecal microbiota transplantation on symptoms of chronic pouchitis are not established, though some studies show promising results. The treatment appears safe, when guidelines for donor screening are followed. Future controlled studies investigating safety, dose, duration, preparation of 
FMT, administration route, and concomitant treatments are needed to establish whether FMT can be a part of the treatment of chronic pouchitis.

Supplementary Materials: The following are available online at http://www.mdpi.com/2076-2607/8/9/1433/s1, Table S1: Search strategy, Table S2: Quality assessment of controlled, interventional studies, Table S3: Quality assessment of cohort studies, and Table S4: Quality assessment of case-series.

Author Contributions: F.C. and S.J.K. contributed equally to this paper. L.H.H. is the guarantor of the review. The concept of the review was proposed by F.C. and L.H.H. The review protocol was drafted by F.C. and S.J.K. and reviewed by all authors before submission. F.C. and S.J.K. designed the research strategy with the aid of S.I.H. and L.H.H., and H.L.N. provided expertise on microbiological analyses and interpretations. A.M.P. and O.T.-U. provided expertise in chronic pouchitis. S.J.K. performed the systematic research of electronic databases with the aid of F.C. F.C. and S.J.K. screened the titles and abstracts of records retrieved from the searches using the predetermined inclusion criteria, where any doubt or disagreement was discussed with A.M.P. F.C. and S.J.K. independently completed data extraction and assessed the quality and risk of bias of the included studies consulting A.M.P. if any disagreements. F.C. provided statistical support for the systematic review. S.J.K. drafted the manuscript. All authors read and approved the final manuscript before submission.

Funding: This study is funded by Danish Innovation Fund (“MicroHealth”, grant number 7076-00129B).

Acknowledgments: University librarian, Conny Skrubbeltang, Medical Library, Aalborg Hospital Science and Innovation Center, DK-9000 Aalborg. Furthermore, we would like to acknowledge the following authors of the included publications who responded with further clarifications of study details; Hans Herfarth, Jon Landy, Ailsa Hart, and Najwa El-Nachef.

Conflicts of Interest: None declared by all authors. The funder had no role in the design of the study; in the collection, analyses, or interpretation of data; in the writing of the manuscript, or in the decision to publish the results.

\section{References}

1. Ng, K.S.; Gonsalves, S.J.; Sagar, P.M. Ileal-anal pouches: A review of its history, indications, and complications. World J. Gastroenterol. 2019, 25, 4320-4342. [CrossRef] [PubMed]

2. Hata, K.; Ishihara, S.; Nozawa, H.; Kawai, K.; Kiyomatsu, T.; Tanaka, T.; Kishikawa, J.; Anzai, H.; Watanabe, T. Pouchitis after ileal pouch-anal anastomosis in ulcerative colitis: Diagnosis, management, risk factors, and incidence. Dig. Endosc. Off. J. Jpn. Gastroenterol. Endosc. Soc. 2017, 29, 26-34. [CrossRef] [PubMed]

3. Gao, X.H.; Li, J.Q.; Khan, F.; Chouhan, H.; Yu, G.Y.; Remer, E.; Stocchi, L.; Hull, T.L.; Shen, B. Difference in the frequency of pouchitis between ulcerative colitis and familial adenomatous polyposis: Is the explanation in peripouch fat? Colorectal Dis. Off. J. Assoc. Coloproctology Great Br. Irel. 2019, 21, 1032-1044. [CrossRef] [PubMed]

4. Shah, H.; Zezos, P. Pouchitis: Diagnosis and management. Curr. Opin. Gastroenterol. 2020, 36, 41-47. [CrossRef] [PubMed]

5. Fazio, V.W.; Kiran, R.P.; Remzi, F.H.; Coffey, J.C.; Heneghan, H.M.; Kirat, H.T.; Manilich, E.; Shen, B.; Martin, S.T. Ileal pouch anal anastomosis: Analysis of outcome and quality of life in 3707 patients. Ann. Surg. 2013, 257, 679-685. [CrossRef] [PubMed]

6. Segal, J.P.; Ding, N.S.; Worley, G.; McLaughlin, S.; Preston, S.; Faiz, O.D.; Clark, S.K.; Hart, A.L. Systematic review with meta-analysis: The management of chronic refractory pouchitis with an evidence-based treatment algorithm. Aliment. Pharmacol. Ther. 2017, 45, 581-592. [CrossRef]

7. Nguyen, N.; Zhang, B.; Holubar, S.D.; Pardi, D.S.; Singh, S. Treatment and prevention of pouchitis after ileal pouch-anal anastomosis for chronic ulcerative colitis. Cochrane Database Syst. Rev. 2019. [CrossRef]

8. Segal, J.P.; Oke, S.; Hold, G.L.; Clark, S.K.; Faiz, O.D.; Hart, A.L. Systematic review: Ileoanal pouch microbiota in health and disease. Aliment. Pharmacol. Ther. 2018, 47, 466-477. [CrossRef]

9. Zella, G.C.; Hait, E.J.; Glavan, T.; Gevers, D.; Ward, D.V.; Kitts, C.L.; Korzenik, J.R. Distinct microbiome in pouchitis compared to healthy pouches in ulcerative colitis and familial adenomatous polyposis. Inflamm. Bowel Dis. 2011, 17, 1092-1100. [CrossRef]

10. McLaughlin, S.D.; Walker, A.W.; Churcher, C.; Clark, S.K.; Tekkis, P.P.; Johnson, M.W.; Parkhill, J.; Ciclitira, P.J.; Dougan, G.; Nicholls, R.J.; et al. The bacteriology of pouchitis: A molecular phylogenetic analysis using $16 \mathrm{~S}$ rRNA gene cloning and sequencing. Ann. Surg. 2010, 252, 90-98. [CrossRef]

11. Li, K.Y.; Wang, J.L.; Wei, J.P.; Gao, S.Y.; Zhang, Y.Y.; Wang, L.T.; Liu, G. Fecal microbiota in pouchitis and ulcerative colitis. World J. Gastroenterol. 2016, 22, 8929-8939. [CrossRef] [PubMed] 
12. Dubinsky, V.; Reshef, L.; Bar, N.; Keizer, D.; Golan, N.; Rabinowitz, K.; Godny, L.; Yadgar, K.; Zonensain, K.; Tulchinsky, H.; et al. Predominantly Antibiotic-resistant Intestinal Microbiome Persists in Patients With Pouchitis Who Respond to Antibiotic Therapy. Gastroenterology 2020, 158, 610-624. [CrossRef] [PubMed]

13. Dalal, R.L.; Shen, B.; Schwartz, D.A. Management of Pouchitis and Other Common Complications of the Pouch. Inflamm. Bowel Dis. 2018, 24, 989-996. [CrossRef] [PubMed]

14. Gionchetti, P.; Calabrese, C.; Lauri, A.; Rizzello, F. The therapeutic potential of antibiotics and probiotics in the treatment of pouchitis. Expert Rev. Gastroenterol. Hepatol. 2015, 9, 1175-1181. [CrossRef] [PubMed]

15. Shen, B. Treatment of chronic and refractory pouchitis. Semin. Colon Rectal Surg. 2017, 28, 138-141. [CrossRef]

16. Verbeke, K.A.; Boesmans, L.; Boets, E. Modulating the microbiota in inflammatory bowel diseases: Prebiotics, probiotics or fecal transplantation? Proc. Nutr. Soc. 2014, 73, 490-497. [CrossRef]

17. Hvas, C.L.; Dahl Jorgensen, S.M.; Jorgensen, S.P.; Storgaard, M.; Lemming, L.; Hansen, M.M.; Erikstrup, C.; Dahlerup, J.F. Fecal Microbiota Transplantation Is Superior to Fidaxomicin for Treatment of Recurrent Clostridium difficile Infection. Gastroenterology 2019, 156, 1324-1332. [CrossRef]

18. Paramsothy, S.; Kamm, M.A.; Kaakoush, N.O.; Walsh, A.J.; van den Bogaerde, J.; Samuel, D.; Leong, R.W.L.; Connor, S.; Ng, W.; Paramsothy, R.; et al. Multidonor intensive fecal microbiota transplantation for active ulcerative colitis: A randomised placebo-controlled trial. Lancet 2017, 389, 1218-1228. [CrossRef]

19. Sokol, H.; Landman, C.; Seksik, P.; Berard, L.; Montil, M.; Nion-Larmurier, I.; Bourrier, A.; Le Gall, G.; Lalande, V.; De Rougemont, A.; et al. Fecal microbiota transplantation to maintain remission in Crohn's disease: A pilot randomized controlled study. Microbiome 2020, 8, 12. [CrossRef]

20. Steube, A.; Vital, M.; Sturm, A.; Buening, C.; Stallmach, A.; Pieper, D. Encapsulated fecal microbiota transfer in patients with chronic, antibiotic-refractory pouchitis. United Eur. Gastroenterol. J. 2017, 5, A307. [CrossRef]

21. Schmid, M.; Frick, J.S.; Malek, N.; Goetz, M. Successful treatment of pouchitis with Vedolizumab, but not fecal microbiota transfer (FMT), after proctocolectomy in ulcerative colitis. Int. J. Colorectal Dis. 2017, 32, 597-598. [CrossRef] [PubMed]

22. Stallmach, A.; Lange, K.; Buening, J.; Sina, C.; Vital, M.; Pieper, D.H. Fecal Microbiota Transfer in Patients With Chronic Antibiotic-Refractory Pouchitis. Am. J. Gastroenterol. 2016, 111, 441-443. [CrossRef] [PubMed]

23. Herfarth, H.; Barnes, E.L.; Long, M.D.; Isaacs, K.L.; Leith, T.; Silverstein, M.; Gerardin, Y.; Kassam, Z. Combined Endoscopic and Oral Fecal Microbiota Transplantation in Patients with Antibiotic-Dependent Pouchitis: Low Clinical Efficacy due to Low Donor Microbial Engraftment. Inflamm. Intest. Dis. 2019, 4, 1-6. [CrossRef] [PubMed]

24. Moher, D.; Liberati, A.; Tetzlaff, J.; Altman, D.G. Preferred reporting items for systematic reviews and meta-analyses: The PRISMA statement. BMJ (Clin. Res. Ed.) 2009, 339, b2535. [CrossRef]

25. Fang, H.; Fu, L.; Wang, J. Protocol for Fecal Microbiota Transplantation in Inflammatory Bowel Disease: A Systematic Review and Meta-Analysis. Biomed Res. Int. 2018, 2018, 8941340. [CrossRef] [PubMed]

26. Castano-Rodriguez, N.; Paramsothy, S.; Kaakoush, N.O. Promise of Fecal Microbiota Transplantation Therapy in Pouchitis. Dig. Dis. Sci. 2019. [CrossRef] [PubMed]

27. Web of Science. Available online: https://clarivate.com/webofsciencegroup/solutions/web-of-science/ (accessed on 21 April 2020).

28. (NIH) U.S. National Library of Medicine. Available online: https://clinicaltrials.gov/ (accessed on 21 April 2020).

29. World Health Organisation. International Clinical Trials Registry Platform (ICTRP). Available online: https://apps.who.int/trialsearch/ (accessed on 21 April 2020).

30. Opengrey. System for Information in Grey Litterature in Europe. Available online: http://opengrey.eu/ (accessed on 21 April 2020).

31. Prospero International Prospective Registry of Systematic Reviews. Available online: https://www.crd.york. ac.uk/PROSPERO/ (accessed on 30 April 2020).

32. Steinhart, A.H.; Ben-Bassat, O. Pouchitis: A practical guide. Frontline Gastroenterol. 2013, 4, $198-204$. [CrossRef] [PubMed]

33. Nishida, A.; Imaeda, H.; Inatomi, O.; Bamba, S.; Sugimoto, M.; Andoh, A. The efficacy of fecal microbiota transplantation for patients with chronic pouchitis: A case series. Clin. Case Rep. 2019, 7, 782-788. [CrossRef] [PubMed]

34. Shen, B.; Achkar, J.P.; Connor, J.T.; Ormsby, A.H.; Remzi, F.H.; Bevins, C.L.; Brzezinski, A.; Bambrick, M.L.; Fazio, V.W.; Lashner, B.A. Modified pouchitis disease activity index: A simplified approach to the diagnosis of pouchitis. Dis. Colon Rectum 2003, 46, 748-753. [CrossRef] [PubMed] 
35. Higgins, J.P.; Altman, D.G.; Gotzsche, P.C.; Juni, P.; Moher, D.; Oxman, A.D.; Savovic, J.; Schulz, K.F.; Weeks, L.; Sterne, J.A. The Cochrane Collaboration's tool for assessing risk of bias in randomised trials. BMJ (Clin. Res. Ed.) 2011, 343, d5928. [CrossRef]

36. NHLBI. Study Quality Assessment Tools, National Heart, Blood and Lung Institute. Available online: https://www.nhlbi.nih.gov/health-topics/study-quality-assessment-tools (accessed on 21 April 2020).

37. Lai, C.Y.; Sung, J.; Cheng, F.; Tang, W.; Wong, S.H.; Chan, P.K.S.; Kamm, M.A.; Sung, J.J.Y.; Kaplan, G.; Chan, F.K.L.; et al. Systematic review with meta-analysis: Review of donor features, procedures and outcomes in 168 clinical studies of fecal microbiota transplantation. Aliment. Pharmacol. Ther. 2019. [CrossRef] [PubMed]

38. Landy, J.; Walker, A.W.; Li, J.V.; Al-Hassi, H.O.; Ronde, E.; English, N.R.; Mann, E.R.; Bernardo, D.; McLaughlin, S.D.; Parkhill, J.; et al. Variable alterations of the microbiota, without metabolic or immunological change, following fecal microbiota transplantation in patients with chronic pouchitis. Sci. Rep. 2015, 5, 12955. [CrossRef] [PubMed]

39. Kousgaard, S.J.; Michaelsen, T.Y.; Nielsen, H.L.; Kirk, K.F.; Brandt, J.; Albertsen, M.; Thorlacius-Ussing, O. Clinical results and microbiota changes after fecal microbiota transplantation for chronic pouchitis: A pilot study. Scand. J. Gastroenterol. 2020, 421-429. [CrossRef] [PubMed]

40. Selvig, D.; Piceno, Y.; Terdiman, J.; Zydek, M.; Umetsu, S.E.; Balitzer, D.; Fadrosh, D.; Lynch, K.; Lamere, B.; Leith, T.; et al. Fecal Microbiota Transplantation in Pouchitis: Clinical, Endoscopic, Histologic, and Microbiota Results from a Pilot Study. Dig. Dis. Sci. 2019. [CrossRef]

41. Theede, K.; Holck, S.; Ibsen, P.; Ladelund, S.; Nordgaard-Lassen, I.; Nielsen, A.M. Level of Fecal Calprotectin Correlates With Endoscopic and Histologic Inflammation and Identifies Patients With Mucosal Healing in Ulcerative Colitis. Clin. Gastroenterol. Hepatol. Off. Clin. Pract. J. Am. Gastroenterol. Assoc. 2015, 13, 1929-1936.e1921. [CrossRef]

42. Fang, S.; Kraft, C.S.; Dhere, T.; Srinivasan, J.; Begley, B.; Weinstein, D.; Shaffer, V.O. Successful treatment of chronic Pouchitis utilizing fecal microbiota transplantation (FMT): A case report. Int. J. Colorectal Dis. 2016, 31, 1093-1094. [CrossRef]

43. Lan, N.; Ashburn, J.; Shen, B. Fecal microbiota transplantation for Clostridium difficile infection in patients with ileal pouches. Gastroenterol. Rep. 2017, 5, 200-207. [CrossRef]

44. Guo, X.Y.; Liu, X.J.; Hao, J.Y. Gut Microbiota in Ulcerative Colitis: Insights on Pathogenesis and Treatment. J. Dig. Dis 2020. [CrossRef]

45. Costello, S.P.; Hughes, P.A.; Waters, O.; Bryant, R.V.; Vincent, A.D.; Blatchford, P.; Katsikeros, R.; Makanyanga, J.; Campaniello, M.A.; Mavrangelos, C.; et al. Effect of Fecal Microbiota Transplantation on 8-Week Remission in Patients With Ulcerative Colitis: A Randomized Clinical Trial. JAMA 2019, 321, 156-164. [CrossRef]

46. Moayyedi, P.; Surette, M.G.; Kim, P.T.; Libertucci, J.; Wolfe, M.; Onischi, C.; Armstrong, D.; Marshall, J.K.; Kassam, Z.; Reinisch, W.; et al. Fecal Microbiota Transplantation Induces Remission in Patients With Active Ulcerative Colitis in a Randomized Controlled Trial. Gastroenterology 2015, 149, 102-109. [CrossRef]

47. Lopetuso, L.R.; Ianiro, G.; Allegretti, J.R.; Bibbò, S.; Gasbarrini, A.; Scaldaferri, F.; Cammarota, G. Fecal transplantation for ulcerative colitis: Current evidence and future applications. Expert Opin. Biol. Ther. 2020, 20, 343-351. [CrossRef] [PubMed]

48. Costello, S.P.; Soo, W.; Bryant, R.V.; Jairath, V.; Hart, A.L.; Andrews, J.M. Systematic review with meta-analysis: Fecal microbiota transplantation for the induction of remission for active ulcerative colitis. Aliment. Pharmacol. Ther. 2017, 46, 213-224. [CrossRef] [PubMed]

49. Wilson, B.C.; Vatanen, T.; Cutfield, W.S.; O'Sullivan, J.M. The Super-Donor Phenomenon in Fecal Microbiota Transplantation. Front. Cell. Infect. Microbiol. 2019, 9, 2. [CrossRef] [PubMed]

50. Staley, C.; Kaiser, T.; Vaughn, B.P.; Graiziger, C.T.; Hamilton, M.J.; Rehman, T.U.; Song, K.; Khoruts, A.; Sadowsky, M.J. Predicting recurrence of Clostridium difficile infection following encapsulated fecal microbiota transplantation. Microbiome 2018, 6, 166. [CrossRef]

51. Sandborn, W.J.; Tremaine, W.J.; Batts, K.P.; Pemberton, J.H.; Phillips, S.F. Pouchitis after ileal pouch-anal anastomosis: A Pouchitis Disease Activity Index. Mayo Clin. Proc. 1994, 69, 409-415. [CrossRef]

52. El-Nachef, N.; Piceno, Y.M.; Kassam, Z.; Zydek, M.; Ablaza, A.J.; Leith, T.; Ma, A.; Somsouk, M.; Terdiman, J.P.; Lynch, S. Fecal microbiota transplantation is safe and effective in chronic pouchitis patients. Gastroenterology 2017, 152, S1009. [CrossRef] 
53. Baxter, M.; Colville, A. Adverse events in fecal microbiota transplant: A review of the literature. J. Hosp. Infect. 2016, 92, 117-127. [CrossRef]

54. Perler, B.K.; Chen, B.; Phelps, E.; Allegretti, J.R.; Fischer, M.; Ganapini, V.; Krajiceck, E.; Kumar, V.; Marcus, J.; Nativ, L.; et al. Long-Term Efficacy and Safety of Fecal Microbiota Transplantation for Treatment of Recurrent Clostridioides difficile Infection. J. Clin. Gastroenterol. 2020. [CrossRef]

55. Cammarota, G.; Ianiro, G.; Tilg, H.; Rajilic-Stojanovic, M.; Kump, P.; Satokari, R.; Sokol, H.; Arkkila, P.; Pintus, C.; Hart, A.; et al. European consensus conference on fecal microbiota transplantation in clinical practice. Gut 2017, 66, 569-580. [CrossRef]

56. FDA. Important Safety Alert Regarding Use of Fecal Microbiota for Transplantation and Risk of Serious Adverse Reactions Due to Transmission of Multi-Drug Resistant Organisms. Available online: https://www.fda.gov/vaccines-blood-biologics/safety-availability-biologics/important-safetyalert-regarding-use-fecal-microbiota-transplantation-and-risk-serious-adverse (accessed on 13 June 2019).

57. Lee, C.H.; Chai, J.; Hammond, K.; Jeon, S.R.; Patel, Y.; Goldeh, C.; Kim, P. Long-term durability and safety of fecal microbiota transplantation for recurrent or refractory Clostridioides difficile infection with or without antibiotic exposure. Eur. J. Clin. Microbiol. Infect. Dis. Off. Publ. Eur. Soc. Clin. Microbiol. 2019, 38, 1731-1735. [CrossRef]

58. Rossen, N.G.; Fuentes, S.; van der Spek, M.J.; Tijssen, J.G.; Hartman, J.H.; Duflou, A.; Lowenberg, M.; van den Brink, G.R.; Mathus-Vliegen, E.M.; de Vos, W.M.; et al. Findings From a Randomized Controlled Trial of Fecal Transplantation for Patients With Ulcerative Colitis. Gastroenterology 2015, 149, 110-118. [CrossRef] [PubMed]

59. Quraishi, M.N.; Widlak, M.; Bhala, N.; Moore, D.; Price, M.; Sharma, N.; Iqbal, T.H. Systematic review with meta-analysis: The efficacy of fecal microbiota transplantation for the treatment of recurrent and refractory Clostridium difficile infection. Aliment. Pharmacol. Ther. 2017, 46, 479-493. [CrossRef] [PubMed]

60. Ng, S.C.; Kamm, M.A.; Yeoh, Y.K.; Chan, P.K.S.; Zuo, T.; Tang, W.; Sood, A.; Andoh, A.; Ohmiya, N.; Zhou, Y.; et al. Scientific frontiers in fecal microbiota transplantation: Joint document of Asia-Pacific Association of Gastroenterology (APAGE) and Asia-Pacific Society for Digestive Endoscopy (APSDE). Gut 2020, 69, 83-91. [CrossRef] [PubMed]

61. Fuentes, S.; van Nood, E.; Tims, S.; Heikamp-de Jong, I.; ter Braak, C.J.; Keller, J.J.; Zoetendal, E.G.; de Vos, W.M. Reset of a critically disturbed microbial ecosystem: Fecal transplant in recurrent Clostridium difficile infection. ISME J. 2014, 8, 1621-1633. [CrossRef] [PubMed]

62. Zuo, T.; Wong, S.H.; Lam, K.; Lui, R.; Cheung, K.; Tang, W.; Ching, J.Y.L.; Chan, P.K.S.; Chan, M.C.W.; $\mathrm{Wu}$, J.C.Y.; et al. Bacteriophage transfer during fecal microbiota transplantation in Clostridium difficile infection is associated with treatment outcome. Gut 2018, 67, 634-643. [CrossRef]

63. Zuo, T.; Wong, S.H.; Cheung, C.P.; Lam, K.; Lui, R.; Cheung, K.; Zhang, F.; Tang, W.; Ching, J.Y.L.; Wu, J.C.Y.; et al. Gut fungal dysbiosis correlates with reduced efficacy of fecal microbiota transplantation in Clostridium difficile infection. Nat. Commun. 2018, 9, 3663. [CrossRef]

64. Lee, S.T.M.; Kahn, S.A.; Delmont, T.O.; Shaiber, A.; Esen, O.C.; Hubert, N.A.; Morrison, H.G.; Antonopoulos, D.A.; Rubin, D.T.; Eren, A.M. Tracking microbial colonization in fecal microbiota transplantation experiments via genome-resolved metagenomics. Microbiome 2017, 5, 50. [CrossRef]

65. Paramsothy, S.; Nielsen, S.; Kamm, M.A.; Deshpande, N.P.; Faith, J.J.; Clemente, J.C.; Paramsothy, R.; Walsh, A.J.; van den Bogaerde, J.; Samuel, D.; et al. Specific Bacteria and Metabolites Associated With Response to Fecal Microbiota Transplantation in Patients With Ulcerative Colitis. Gastroenterology 2019, 156, 1440-1454. [CrossRef]

66. El-Salhy, M.; Hatlebakk, J.G.; Gilja, O.H.; Brathen Kristoffersen, A.; Hausken, T. Efficacy of fecal microbiota transplantation for patients with irritable bowel syndrome in a randomised, double-blind, placebo-controlled study. Gut 2019. [CrossRef]

67. Fuentes, S.; Rossen, N.G.; van der Spek, M.J.; Hartman, J.H.; Huuskonen, L.; Korpela, K.; Salojarvi, J.; Aalvink, S.; de Vos, W.M.; D'Haens, G.R.; et al. Microbial shifts and signatures of long-term remission in ulcerative colitis after fecal microbiota transplantation. ISME J. 2017, 11, 1877-1889. [CrossRef]

68. Vrieze, A.; Van Nood, E.; Holleman, F.; Salojarvi, J.; Kootte, R.S.; Bartelsman, J.F.; Dallinga-Thie, G.M.; Ackermans, M.T.; Serlie, M.J.; Oozeer, R.; et al. Transfer of intestinal microbiota from lean donors increases insulin sensitivity in individuals with metabolic syndrome. Gastroenterology 2012, 143, 913-916. [CrossRef] [PubMed] 
69. Kelly, C.R.; Kahn, S.; Kashyap, P.; Laine, L.; Rubin, D.; Atreja, A.; Moore, T.; Wu, G. Update on Fecal Microbiota Transplantation 2015: Indications, Methodologies, Mechanisms, and Outlook. Gastroenterology 2015, 149, 223-237. [CrossRef]

70. Barnes, D.; Ng, K.; Smits, S.; Sonnenburg, J.; Kassam, Z.; Park, K.T. Competitively Selected Donor Fecal Microbiota Transplantation: Butyrate Concentration and Diversity as Measures of Donor Quality. J. Pediatr. Gastroenterol. Nutr. 2018, 67, 185-187. [CrossRef] [PubMed]

71. Ramai, D.; Zakhia, K.; Ofosu, A.; Ofori, E.; Reddy, M. Fecal microbiota transplantation: Donor relation, fresh or frozen, delivery methods, cost-effectiveness. Ann. Gastroenterol. 2019, 32, 30-38. [CrossRef]

72. Kao, D.; Roach, B.; Silva, M.; Beck, P.; Rioux, K.; Kaplan, G.G.; Chang, H.J.; Coward, S.; Goodman, K.J.; Xu, H.; et al. Effect of Oral Capsule- vs Colonoscopy-Delivered Fecal Microbiota Transplantation on Recurrent Clostridium difficile Infection: A Randomized Clinical Trial. JAMA 2017, 318, 1985-1993. [CrossRef] [PubMed]

73. Cold, F.; Browne, P.D.; Günther, S.; Halkjaer, S.I.; Petersen, A.M.; Al-Gibouri, Z.; Hansen, L.H.; Christensen, A.H. Multidonor FMT capsules improve symptoms and decrease fecal calprotectin in ulcerative colitis patients while treated-An open-label pilot study. Scand. J. Gastroenterol. 2019, 54, 289-296. [CrossRef]

74. Terveer, E.M.; van Beurden, Y.H.; Goorhuis, A.; Seegers, J.; Bauer, M.P.; van Nood, E.; Dijkgraaf, M.G.W.; Mulder, C.J.J.; Vandenbroucke-Grauls, C.; Verspaget, H.W.; et al. How to: Establish and run a stool bank. Clin. Microbiol. Infect. Off. Publ. Eur. Soc. Clin. Microbiol. Infect. Dis. 2017, 23, 924-930. [CrossRef] [PubMed]

75. Cammarota, G.; Ianiro, G.; Kelly, C.R.; Mullish, B.H.; Allegretti, J.R.; Kassam, Z.; Putignani, L.; Fischer, M.; Keller, J.J.; Costello, S.P.; et al. International consensus conference on stool banking for fecal microbiota transplantation in clinical practice. Gut 2019, 68, 2111-2121. [CrossRef]

76. Barnes, E.L.; Herfarth, H.H.; Sandler, R.S.; Chen, W.; Jaeger, E.; Nguyen, V.M.; Robb, A.R.; Kappelman, M.D.; Martin, C.F.; Long, M.D. Pouch-Related Symptoms and Quality of Life in Patients with Ileal Pouch-Anal Anastomosis. Inflamm. Bowel Dis. 2017, 23, 1218-1224. [CrossRef]

(C) 2020 by the authors. Licensee MDPI, Basel, Switzerland. This article is an open access article distributed under the terms and conditions of the Creative Commons Attribution (CC BY) license (http://creativecommons.org/licenses/by/4.0/). 